Jurnal Pena Sains Vol. 8, No. 1, April, 2021

p-ISSN: 2407-2311

e-ISSN: 2527-7634

\title{
DEVELOPMENT OF INTEGRATED SCIENCE LEARNING INSTRUMENTS USING A HUMANISTIC APPROACH WITH ECONOMIC DRAWINGS
}

\author{
Anis Zahrotin ${ }^{1}$ \\ ${ }^{1}$ Program StudiPendidikan IPA, STKIP Modern Ngawi \\ aniszahrotin1@gmail.com \\ Accepted: April 14, 2021 \\ Published: April 30, 2021 \\ DOI: $10.21107 /$ jps.v8i1.10104
}

\begin{abstract}
Research on the development of integrated science learning instruments helps students to develop their potential and character. The research involved the use of lesson plans, worksheets, syllabus, props, and modules through four stages, namely the Four-D Model flow, namely definition, design, development, and dissemination. This research was conducted at MTsN 4 Bojonegoro. The research method is qualitative research by observing the field and collecting data based on the results of tests and questionnaires. The results of the study are as follows 1) students are more motivated to use teaching aids in integrated science learning, 2) by using economic teaching aids, students get an increase in cognitive knowledge and also character education and understand the relationship between knowledge and attitudes or actions in everyday life, 3) integrated science learning with economic aids should be used more intensively in science learning with different themes, 4) Each subject should provide opportunities for the teaching staff to develop economic teaching aids by utilizing used tools and materials from the surrounding environment.
\end{abstract}

Keywords: Science Integrated, education character, humanistic approach, economical

${ }^{1}$ Corresponding Author 


\section{Introduction}

Every child must have intelligence and talents embedded in him that are expected to be honed and sharpened with education. The purpose of education itself, according to Law no. 20 of 2003 article 3 concerning the National Education System, is to develop students' abilities to become individuals who believe and fear God, have a noble character, are creative, independent, healthy, knowledgeable, and become democratic citizens who are also responsible. However, on the other hand, the existence of an evaluation system such as a generalized exam measures the relative aspects of student intelligence and dwarfs each student's different potential. The focus of learning that is centered on developing cognitive abilities alone has ignored human values as a reflection of Pancasila values. There is often violence experienced by students whose cognitive abilities are deemed not up to standards so that violence in the Indonesian education world is often found (Muis, Syafiq \& Savira, 2011). This is, of course, contrary to character education as a Pillar of National Awakening according to the theme of National Education Day 2011. A personality that rests on pride and love for the nation and the Pancasila State, Bhineka Tunggal Ika, UUD 1945, and NKRI as its pillars.

Character education is aimed at developing and instilling character in students so that they have a noble personality and apply it in everyday life both at home, school and in the surrounding community (Wibowo, 2013). From this understanding, character education is, of course, very much needed by students, and one of them can be instilled through learning science by using a contextual approach (Khusniati, 2012). Through humanistic learning instruments based on constructivism, assisted by learning through $\mathrm{CD}$ has resulted in learning achievement to achieve completeness, and the experimental class is better than the control class (Widyanto, Rusilowati, \& Waluyo, 2013). Not only with learning CD, but research using science teaching aids made using used materials also maximizes students in learning; another positive impact is making students accustomed to protecting and conserving the surrounding environment (Widiyatmoko and Pamelasari, 2012).

Science learning is essential in the 2013 curriculum implemented in an integrated manner in schools. This is in line with the opinion of the experts who said that the 2013 curriculum requires science learning to be carried out in an integrated manner in SMP / MTs (Asrizal, 2017). The essence of science learning can be classified into three, namely natural science as a product, process, and scientific attitude. Natural science learning at elementary school age must be carried out fundamentally and in a real way. Through science education, it is hoped that can foster logical, rational, analytical, and critical thinking skills in students to support the development of science and technology (Wangsa. et al, 2021). The biggest obstacle faced by some schools, both public and private, is the lack of facilities and infrastructure (Apriana, 2017) inadequate provision of facilities and infrastructure, from teachers who still lack understanding of the use of tools and materials, (Setyaningsih, 2018) State the role and function of educational facilities and infrastructure which is one of the important resources in supporting the learning process

Science lessons that are generally considered difficult by students will be easier to understand if the teaching staff uses interesting learning media. This teaching aid can mean educational media that aims to stimulate interest in learning and foster motivation of students so that they are not bored to achieve learning goals (Wijaya \& Rusyan, 1994). Teaching aids that can be made by teaching staff and students can be in the form of simple tools that are easy to make from materials in the surrounding environment so that the use of props can be created at a more economical and affordable cost and under the concepts being taught (Widiyatmoko \& Pamelasari, 2012). Based on the experience of science teachers, the use of tools or teaching aids helps teachers and students to achieve learning goals. The existence of teaching aids not only helps the teacher to explain science lessons but also helps students understand the science lesson, increases students' desire to learn science, and also optimizes all student sensory functions by seeing, feeling, listening, and using their thoughts scientifically. Logical and realistic. The purpose of the humanistic approach itself is to develop positive character (self-direction) and student independence or freedom (Arsury, 2007). Constructivism will give children the freedom to build their knowledge through organizational experiences and interactions with the surrounding environment (Abdullah, 2018).

The theory of humanistic learning is defined as an activity of physical and spiritual activities to maximize the development process. Meanwhile, learning is defined as an effort to master the treasures of science as a series of individual activities as a whole. Social growth does 
not lead to behavioral development. Change or development is only caused by a change learning process such as habits, various abilities in terms of knowledge, attitudes, and skills. Humanistic education or the concept of humanistic learning cannot be separated from the flow of humanistic psychology, as the basis or source of the concept of humanistic education (Akmal et al, 2019). This understanding is an invitation for humans to improve the quality of themselves towards their potential for life, with the development of the educational era also changing humanistic to provide a solution to achieve a goal. can always develop the potential for learning against himself (Anany \& Ashiefatul, 2010).

The function of teaching aids in integrated science learning, but in reality, in the field, the existing science learning instruments are not very supportive. So that the teacher is not optimal in developing the potential of students, including the formation of the character of these students, based on this background, a character education Integrated Science learning design using a humanist approach assisted by economic teaching aids is needed. It can be formulated that the problem in this study is how to expand the Integrated Science learning instrument character education using a humanistic approach with valid economic props?

\section{Research Methods}

The length of the study was 2 months (February-March 2021). Research data collection will be carried out in the even semester of the 2020/2021 school year. As the subject of this research is a class VII student of MTsN 4 Bojonegoro. This research was conducted at MTsN 4 Bojonegoro which is addressed Bojonegoro East Java. This research is a Research and Development ( $\mathrm{R} \& \mathrm{D})$ research. The instruments that will be expanded in this research are syllabus, economic props, lesson plans, student worksheets, and evaluation of learning achievement. The research tools included the application of character values or student activity sheets, the teacher's ability sheet in creating a humanistic classroom, distributing questionnaires containing student responses to learning instruments and the science learning process, and also questionnaires containing teacher responses to learning instruments and learning processes. The subjects of this study were students of class VIII MTsN 4 Bojonegoro.

The research stage includes the defining stage (namely preliminary-end analysis, student analysis, concept analysis, task analysis, and specification of learning objectives), the design stage (in the form of compiling test criteria, selecting props, selecting formats, and initial design) and the development stage. (in the form of expert assessments, legibility tests, and lesson plans simulation, testing props, and research instruments). At the same time, the learning device development procedure used the 4-D model, which includes three stages, namely definition, design, and development. At the same time, the data collection technique is done first by the documentation method by obtaining the initial data used to determine the Development class and the control class as well as information on the initial conditions of the learning instrument. Second, the test method, where this method is used to obtain student achievement data, then the observation method to obtain information on student activity data and the ability of teachers to deliver learning material, and also the questionnaire method to obtain information on student and teacher responses about learning instruments and the learning process.

\section{Result and Discussion}

Expansion of integrated science character education learning instruments using a humanistic approach assisted by economic teaching aids including syllabus, student worksheets, lesson plans for teaching materials, and economic teaching aids. The expanded Integrated Science syllabus is a blend of chemistry and biology syllabus. The integrated syllabus is a combination of SK 1, which understands human life systems, and SK 4 in Chemistry, which understands chemicals in life. Basic Competence is a combination of describing the human respiratory system and its relationship to health, describing the effects and properties of addictive and psychotropic substances, and avoiding the influence of these substances. Validation of the syllabus is carried out by the integrated science teaching staff validator and states that the integrated science syllabus of character education with a humanistic approach supported by economic teaching aids falls into the very good category. Some suggestions given are for the syllabus format to be added with biology and chemistry subjects, adding indicators, and also examples of instruments to make it clearer. The RPP that will be expanded is the RPP IPA integrated character education with a humanistic approach. The lesson plans for learning include identity in the form of school names, subjects, classes and themes, basic 
competencies and competency standards, learning materials, learning objectives, student characters, learning methods and models, learning steps from preparation, early learning, core activities, and final activities, instructional media, learning resources and finally assessment.

The integrated IPA RPP with a humanistic approach assisted by economic props is included in the good category, with input for adding prerequisite knowledge in preliminary activities, adding indicators in the assessment section, and using props in core activities. One example of integrated science worksheets with the theme "Cigarettes and Health" after going through validation activities aims to explain the negative effects of smoking on the economy and social and health and explain how to avoid smoking. This goal is one part of the humanist approach, namely to prevent and prevent students from the effects of smoking.

Science learning materials are prepared using separate teaching materials between biology, chemistry, and physics. The teaching material developed is a learning package that is related to one unit of learning material. The purpose of teaching materials is so that students can achieve and complete their learning objectives both individually and in groups so that students can control their learning abilities and intensity. For example, in the teaching materials for the theme "Cigarettes and Health," there is a combination of lessons on the human respiratory system, chemicals in cigarettes, addictive substances, and psychotropics, and the relationship between human respiratory system disorders and smoking.

Aids or teaching aids are needed in the learning process. The use of this teaching aid will help students to imagine and motivate students to generate motivation and desire of students in learning. Teaching aids also give a deep impression to students because they will use all five senses to learn. Stimulation of student interest and their five senses needs to be involved in learning so that students not only know the theory but can also use and apply what they learn. The economic prop used for "cigarettes and health" is to utilize used materials around the environment. The used materials include hoses and triangular hoses, 1 liter used plastic bottles, boards, balloons, glue, rubber, scissors, hammers, nails, and wire.

This economic teaching aid is successful in showing students how the human breathing mechanism and also the tar content in cigarettes. As a replica of the human breathing mechanism, students are instructed to pull the lower balloon and two balloons that act as lungs, and students will see the lungs expand and collapse as they pull the balloon. The second thing to see the tar content in cigarettes is to light the cigarette and put it in the mouth of the tube; then, the students pull the balloon so that the cotton will look brown. This economic teaching aid helps students to understand the human respiratory system and the harmful effects of smoking. The application of this teaching aid includes learning outcomes and learning completeness, student responses, and character. Based on the value analysis before and after the test carried out before and after the character integrated science learning using a humanistic approach assisted by economic props, the learning outcomes of students (Tabel 1).

Table 1. Learning outcomes Before test and After the test

\begin{tabular}{cccc}
\hline No & Result & Pretest & Post-test \\
\hline 1 & Average & 55 & 82,5 \\
2 & The Higher Score & 65 & 90 \\
3 & Lowest Value & 45 & 75 \\
4 & complete & 20 & 90 \\
5 & not complete & 80 & 10 \\
\hline
\end{tabular}

This table. 1 shows the learning outcomes before and after the test. The mean score before the trial was 55 with $20 \%$ completeness in learning, while the percentage of students who did not complete was $80 \%$. The average value after the test is 82.5 , with learning completeness of $90 \%$ and incomplete by $10 \%$.

The character of students assessed in integrated science learning assisted by economic props is respect, discipline, diligence, attention, responsibility, healthy lifestyle, thoroughness, logical thinking, environmental care, and also curiosity. The results of the assessment of the student character education observation sheet can be seen in Table 2 .

Table 2.Character Value

\begin{tabular}{ccccc}
\hline No & Result & $\begin{array}{c}\text { Low } \\
(\mathbf{\%})\end{array}$ & $\begin{array}{c}\text { Moderate } \\
(\mathbf{\%})\end{array}$ & $\begin{array}{c}\text { High } \\
(\mathbf{\%})\end{array}$ \\
\hline 1 & Attention & 20 & 70 & 10 \\
2 & Be persistent & 15 & 60 & 25 \\
3 & Responsible & 12 & 75 & 13 \\
4 & Thorough & 10 & 50 & 40 \\
5 & Discipline & 15 & 77 & 8 \\
6 & Environmental & 5 & 15 & 80 \\
7 & care & & & \\
7 & Healthy Lifestyle & 10 & 40 & 50 \\
8 & Think Logically & 10 & 70 & 20 \\
\hline
\end{tabular}


Student response data to integrated science learning character education using a humanistic approach assisted by economic props in the form of student responses obtained at the end of the lesson. Table 3 are the results of student responses.

Table 3. Student Response Results

\begin{tabular}{clcc}
\hline \multirow{2}{*}{ No } & \multicolumn{1}{c}{ Question } & \multicolumn{2}{c}{$\begin{array}{c}\text { Student } \\
\text { Responses (\%) }\end{array}$} \\
\cline { 2 - 4 } & \multicolumn{1}{c}{ Yes } & No \\
\hline 1 & $\begin{array}{l}\text { Do the props make it easier to } \\
\text { understand the material } \\
\text { presented? }\end{array}$ & 79 & 3 \\
2 & $\begin{array}{l}\text { Are you interested in learning } \\
\text { science using teaching aids? }\end{array}$ & 95 & 5 \\
3 & $\begin{array}{l}\text { Do you like the activities carried } \\
\text { out in science learning? }\end{array}$ & 92 & 8 \\
4 & $\begin{array}{l}\text { Are the teaching aids suitable to } \\
\text { be applied with science learning } \\
\text { on the theme of smoking and } \\
\text { health }\end{array}$ & 93 & 7 \\
5 & $\begin{array}{l}\text { Does the teacher like to explain } \\
\text { with props? }\end{array}$ & 95 & 5 \\
6 & $\begin{array}{l}\text { Is it motivated to learn to use } \\
\text { teaching aids? }\end{array}$ & 95 & 5 \\
7 & $\begin{array}{l}\text { Do you have difficulty using } \\
\text { teaching aids in science } \\
\text { learning? }\end{array}$ & 90 & 10 \\
\hline 8 & $\begin{array}{l}\text { Is learning using teaching aids } \\
\text { fun? }\end{array}$ & 96 & 4 \\
\hline
\end{tabular}

Based on the table above, it can be seen that students are very happy when the teacher explains the lesson using teaching aids. In the learning process, students like the activities carried out in the classroom, especially when students use these props. Students like props because they don't get bored quickly, and they can work together with their friends in groups when making and applying these props. The way the teacher teaches using teaching aids also affects students' interest and motivation in learning so that it fosters a high sense of curiosity. However, some students' difficulties in learning science are also obstacles in the teaching and learning process as students have difficulty using props with expiratory themes.

Based on the table above, it can be seen that students are very happy when the teacher explains the lesson using teaching aids. In the learning process, students like the activities carried out in the classroom, especially when students use these props. Students like props because they don't get bored quickly, and they can work together with their friends in groups when making and applying these props. The way the teacher teaches using teaching aids also affects students' interest and motivation in learning so that it fosters a high sense of curiosity. However, some students' difficulties in learning science are also obstacles in the teaching and learning process as students have difficulty using props with expiratory themes.

The teacher's way of teaching greatly influences the meaning of students' experiences while learning. In-depth learning experiences will show the connection between conceptual elements and make the learning process more active and effective. Conceptual linkages and alignment of science material will form a cognitive schema that makes students obtain the integrity of knowledge. The integrity of learning science is a view of life, natural phenomena, and the real world that can only be reflected through an integrated science learning process. This learning is packaged with a theme about a concept or discourse that is discussed from various scientific disciplines or various points of view that are easy for students to understand and understand.

In the integrated science learning process, a theme will be discussed from various aspects of the field of science studies. The theme "smoking and health" itself combines two Competency Standards as previously described, namely Understanding various systems in human life with Basic Competencies describing the human respiratory system. Chemical competency standards, namely understanding chemicals in life with basic competencies to describe the effects or properties of addictive and psychotropic substances. So, through integrated science learning, several concepts that are suitable to be used as themes for science learning will not be discussed repeatedly in different subjects so that the use of time for discussing these materials can be more effective and efficient. This learning has also proven to make it easier for students to understand integrated science lessons, as well as motivating students to recognize, accept, absorb and understand the relationship between knowledge (in this case, the human respiratory system) and actions or values contained in the theme (smoking). With an integrated science learning model, students are led to think broadly and deeply and can also understand the relationship between science and attitudes or actions. Students will be accustomed to thinking directed, whole, thorough, regular, analytical, and systemic. Students' interest and desire to learn will also be more motivated if they feel that learning is meaningful to them and they can apply it in their lives. Inside, the props are also equipped with information from the subject matter. The purpose of this teaching aid with the theme of smoking and health is to find out the human respiratory mechanism and also to know the harmful content 
in cigarettes. The teacher also added pictures of human lungs to make it easier for students to understand the learning material. For economic reasons, these props are certainly very economical because most of the tools and materials needed come from used goods in the surrounding environment. Humanistic theory in Integrated Science learning is also related to the character values obtained by students, namely the character values of respect, discipline, diligence, attention, responsibility, healthy lifestyle, thoroughness, logical thinking, environmental care, and also curiosity.

Students will be accustomed to thinking directed, whole, thorough, regular, analytical, and systemic. Students' interest and desire to learn will also be more motivated if they feel that learning is meaningful to them and they can apply it in their lives. Inside, the props are also equipped with information from the subject matter. The purpose of this teaching aid with the theme of smoking and health is to find out the human respiratory mechanism and also to know the harmful content in cigarettes. The teacher also added pictures of human lungs to make it easier for students to understand the learning material. For economic reasons, these props are certainly very economical because most of the tools and materials needed come from used goods in the surrounding environment. Humanistic theory in Integrated Science learning is also related to the character values obtained by students, namely the character values of respect, discipline, diligence, attention, responsibility, healthy lifestyle, thoroughness, logical thinking, environmental care, and also curiosity.

\section{Conclusion}

Expansion of integrated science learning instruments for character education using a humanistic approach to help with economic teaching aids in secondary schools in the form of syllabus, worksheets, lesson plans, props, and the resulting modules Based on the results of research and observations, the following points were obtained: 1) students are more motivated to use teaching aids in integrated science learning, 2) by using economic teaching aids, students get an increase in cognitive knowledge and also character education and understand the relationship between knowledge and attitudes or actions in everyday life, 3) integrated science learning with economic aids should be used more intensively in science learning with different themes, 4) In each subject, it should provide opportunities for teachers to develop economic teaching aids by utilizing tools and used materials from the surrounding environment.

\section{Acknowledgment}

Researchers would like to thank the Validators, Observers, Principals, and all teachers and employees of MTsN 4 Bojonegoro, who have helped a lot during the research.

\section{References}

Abduh, M. (2018). Bermain Dan Regulasi Diri (Kajian Teori Vygotsky). The Second Progressive and Fun Education Seminar. ISBN: 978-602-361-102-7. Retrieved from https://publikasiilmiah.ums.ac.id/handle/116 $\underline{17 / 9568}$

Akmal, A., Said, N., \& Mustami, M. K.. (2018). Pembelajaran Pendidikan Agama Islam Humanistik dengan Pendekatan Active Learning. Jurnal Diskursus Islam (6) Vol. 3.

https://doi.org/10.24252/jdi.v6i3.6543

Anany \& Ashiefatul (2010). Pemikiran Humanistik dalam Pendidikan. Malang: UIN Maulana Malik Ibrahim.

Asrizal, A., Festiyed, F., \& Sumarmin, R. (2017). Analisis Kebutuhan Pengembangan Bahan Ajar IPA Terpadu Bermuatan Literasi Era Digital untuk Pembelajaran Siswa SMP Kelas VIII. Jurnal Eksakta Pendidikan (JEP). $\quad 1(1), \quad 1-8 . \quad$ DOI: https://doi.org/10.24036/jep/vol1-iss1/27

Apriana, D. (2017). Problematika Guru dari Aspek Ketersediaan Sarana Prasarana Menghadapi Era Standarisasi Pendidikan Nasional. Prosiding Seminar Nasional Pendidik. Vol 2 No.1. Published 16 September 2017 in FKIP Universitas Muhammadiyah Palembang Retrieved from http://fkip.umpalembang.ac.id/wpcontent/uploads/2018/02/Dewi-Apriana.pdf

Khusniati, M. (2012). Pendidikan IPA Melalui Pembelajaran IPA. Jurnal Pendidikan IPA Indonesia. Vol. 1(2): 204-210. DOI: https://doi.org/10.15294/jpii.v1i2.2140

Muis, T., Syafiq, M., \& Savira, S. I. (2011). Bentuk, Penyebab, dan Dampak dari Tindak Kekerasan Guru Terhadap Siswa Dalaminteraksi Belajar Mengajar dari 
Perspektifsiswa di SMPN Kota Surabaya: Sebuah Survey. Jurnal Psikologi: Teori \& Terapan, Vol. 1, No. 2, Pebruari 2011. DOI: http://dx.doi.org/10.26740/jptt.v1n2

Nurfa, A. (2012). Penggunaan Alat Peraga Sistem Pernapasan Manusia Pada Kualitas Belajar Siswa SMP Kelas VIII. Unnes Science Education Jurnal (USEJ). Vol. 1 (2): 60-69. DOI: $\underline{10.15294 / \text { USEJ.V1I2.865 }}$

Setyaningsih, S. (2018). Pengelolan Sarana Prasarana dalam Implementasi Kurikulum Pendidikan Guru Sekolah Dasar. Jurnal Manajemen Pendidikan. Vol. 1 (2): 62-71. DOI: $\underline{10.23917 / j m p . v 13 i 2.6397}$

Wangsa, G. N. A. S., Dantes, N., \& Suastra, I. W. (2021). Pengembangan Instrumen Kemampuan Berpikir Kritis dan Hasil Belajar IPA Kelas V SD Gugus IV Kecamatan Gerokgak. Jurnal Pendidikan Dasar Indonesia. Vol. 5 (1). DOI: https://doi.org/10.23887/jurnal_pendas.v5i1. $\underline{267}$

Wibowo, Agus. (2013). Pendidikan Karakter $D i$ Perguruan Tinggi. Yogyakarta: Pustaka Pelajar.

Widada. (2010). Mudah Membuat Media Pembelajaran Multimedia Interaktif. Yogyakarta: Pustaka Widyatama.

Widiyatmoko, A \& Pamelasari, S. D. (2012). Pembelajaran Berbasis Proyek Untuk Mengembangkan Alat Peraga IPA Dengan Memanfaatkan Bahan Bekas Pakai. Jurnal Pendidikan IPA Indonesia. Vol. 1(1): 51-56. DOI: https://doi.org/10.15294/.v1i1.2013

Widyanto, Y., Rusilowati, A., \& Waluya, S. (1). Pengembangan Perangkat Pembelajaran Matematika Humanistik Berbasis Konstruktivisme Berbantuan CD Pembelajaran Materi Sudut dalam Ruang Kelas X. Unnes Journal of Mathematics Education Research, 1(1). Retrieved from https://journal.unnes.ac.id/sju/index.php/ujm er/article/view/20 